
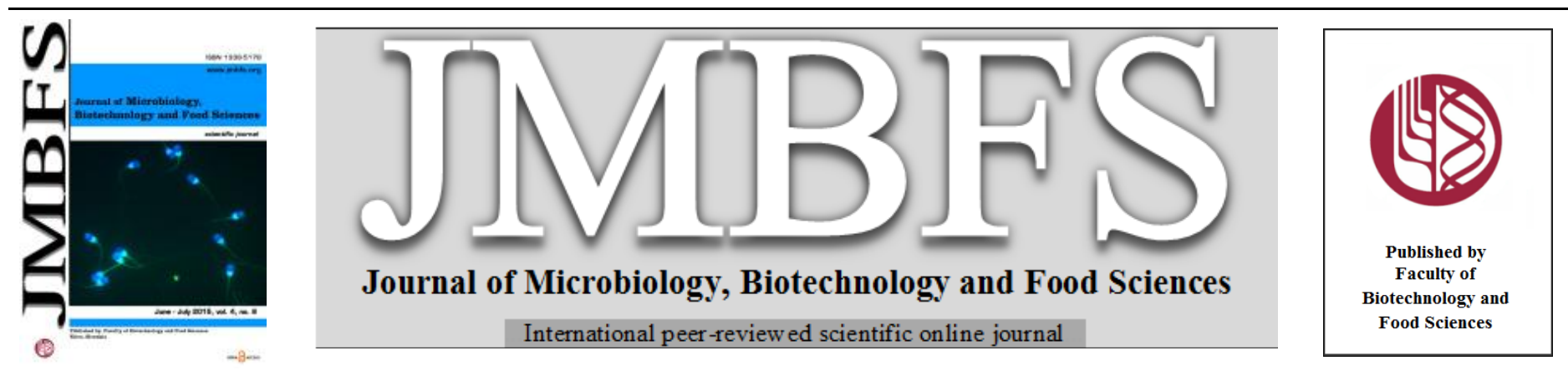

\title{
DEVELOPMENT OF TOFU PRODUCTION METHOD WITH PROBIOTIC BACTERIA ADDITION
}

\section{Dorota Zielińska*, Anna Kamińska, Danuta Kołożyn-Krajewska}

\author{
Address(es): dr inż. Dorota Zielińska, \\ Warsaw University of Life Sciences - SGGW, Faculty of Human Nutrition and Consumer Sciences, Department of Catering Technology and Food Hygiene,
} Nowoursynowska street 159c, 02-776 Warsaw, Poland, phone number: (+48)0-225937068.

*Corresponding author: dorota_zielinska@sggw.pl

doi: 10.15414/jmbfs.2015.4.6.485-490

\section{ARTICLE INFO}

Received 13. 11. 2013

Revised 27. 5. 2014

Accepted 8. 4. 2015

Published 1. 6. 2015

Regular article OPEN $\partial_{\text {ACCESS }}$

\section{ABSTRACT}

The aim of the study was to develop a production method for tofu with probiotic bacteria under laboratory conditions. The works included: selection of a strain and tofu production conditions, and a storage test of the manufactured product.

It was concluded that the sensory quality of tofu with the addition of different probiotic cultures did not differ significantly ( $\mathrm{p}>0.01$ ), depending on used strains and their mixtures, and the sample quality was comparable to the commercial product. It was observed that the number of Lactobacillus bacteria in study samples was the factor determining the palatability of tofu ( $\mathrm{r}=0.75)$. On the other hand, the sensory quality of products was significantly affected by the production method of tofu with the addition of probiotic bacteria. It was concluded that the formation of curds from soy beverage by the addition of $\mathrm{CaSO}_{4}$, followed by inoculation with Lactobacillus casei ŁOCK 0900 at the amount of $9.26 \log \mathrm{CFU} / \mathrm{g}$ and incubation at temp. of $37^{\circ} \mathrm{C}$ for $2 \mathrm{~h}$ as well as for $20 \mathrm{~h}$ are methods recommended for production tofu with regard to sensory qualities of the final product among all tested methods. The number of lactic acid bacteria in studied tofu samples was maintained at the high level $\left(10^{9}-10^{10} \mathrm{CFU} / \mathrm{g}\right)$, and the number of Bifidobacterium animalis ssp lactis BB-12 bacteria did not exceed $10^{3} \mathrm{CFU} / \mathrm{g}$, whereas the number of Lactobacillus bacteria was equal to $10^{8}-10^{9} \mathrm{CFU} / \mathrm{g}$. For the period of 15 days of storage of tofu with probiotic bacteria at the temperature of $4^{\circ} \mathrm{C}$ the number of lactic acid bacteria was maintained at the constant level of approx. $10^{9} \mathrm{CFU} / \mathrm{g}$.

It was concluded that it is possible to produce tofu with probiotic bacteria that has acceptable sensory characteristics and a high number of lactic acid bacteria, therefore the product could be considered as a functional one.

\section{INTRODUCTION}

Probiotic bacteria are defined as "live microorganisms that when administered in adequate amounts could confer a health benefit on the host" (FAO/WHO, 2002). Probiotic bacteria exhibit a range of health benefits such as among others: they stabilise or change microflora of the gastrointestinal tract, participate in the fermentation of saccharides that have not been digested by the body and produce such organic acids as acetic, lactic, propionic and butyric acid. Low $\mathrm{pH}$ also inhibits putrefaction in the lower gastrointestinal tract, a process during which ammonia and amines that are toxic to the body are formed. Moreover, they produce bacteriocins, namely substances that act antagonistically towards relative bacteria, and moreover, inhibit the growth of pathogenic strains: Escherichia Salmonella, Listeria, Klebsiella and Staphylococcus (Nagpal et al., 2012; Liong, 2007). Numerous studies have proven that as a result of probiotic consumption the risk of traveller's diarrhoea is lowered, symptoms are reduced and duration of some infective diarrhoeas caused by bacteria, parasites and viruses is shortened; moreover, it prevents from the development or relieves the course of diarrhoea after antibiotic treatment (van Niel et al., 2002). Another benefit resulting from the consumption of probiotics as part of a diet is their ability to reduce cholesterol absorption, and as a result its blood levels are reduced (Ooi and Liong, 2010). Probiotics affect better bioavailability and assimilation of individual nutritional components, they synthesise some vitamins, mainly of the B group, but also PP vitamin and probably $\mathrm{K}$ vitamin. They increase absorption of minerals and vitamins. Probiotics help digest lactose in those with poorer tolerance of this sugar. Lactic acid bacteria are a source of lactase, an enzyme that hydrolyses lactose into simple sugars, namely glucose and galactose. Hydrolysis products in this form can be absorbed by the intestinal wall without limits. As a result of fermentation diet components can be used more effectively; e.g. lactic acid bacteria hydrolyse mono- and disaccharides, and Bifidobacterium mainly oligoand polysaccharides (Vasiljevic and Shah, 2008; Oelschlaeger, 2010).

Probiotic bacteria are more and more often used in industrial production of fermented foods. First of all, fermentation is used to conserve food in dairy industry, but also in meat and fruit-vegetable industries. Reasons why probiotics are used in plant-derived products include high nutritional and sensory values of these raw materials and a long tradition of fermentation. In a vegetarian diet that has become more and more popular only plant-derived products are consumed by rule, and only such products can be a potential source of probiotics. The use of probiotics in plant-derived products is justified by economic and cultural factors as well as climatic conditions, especially in the Asian countries where there is no tradition of dairy product consumption, but where, on the other hand, fermented vegetables, fruit and cereals, including soy, are consumed (Rivera-Espinoza and Gallardo-Navarro, 2010; Trząskowska, 2013).

In the past the majority of traditional soy products used to be from China. With time they have been introduced into other parts of Asia and Europe. Soy products can be divided into two groups: fermented and unfermented products. Fermented soy products include tempeh, natto, shoyu, miso and sufu. On the other hand, traditional, unfermented soy products include soy milk and tofu (RiveraEspinoza and Gallardo-Navarro, 2010).

Tofu is often called soy cheese. It is a high-protein unfermented product. The production process consists in the addition of a coagulant to soy milk - calcium or magnesium sulphate, calcium chloride and gluconolactone are used the most frequently. Precipitated protein is transferred to containers and pressed. Curd structure is obtained by adding calcium sulphate to milk, and magnesium sulphate is added to obtain gel structure. When gluconolactone is used for coagulation, a softer version, so called silken tofu can be obtained. High-calcium tofu contains $128 \mathrm{mg}$ calcium $/ 100 \mathrm{~g}$, whereas the level of this element in milk is lower - 117 mg/100g (Obatolu, 2008; Jooyandeh, 2011).

The main reservation of consumers with regard to soy products is their taste that is described as typical of soy - grass-like or tart, and another is that they often cause flatulence. The purpose of soy fermentation is to remove the undesirable beanie taste (Wang et al., 2002, 2003, 2006) which is mostly due to the presence of $n$-hexanal and pentanal (Scalabrini et al., 1998), and to improve on the nutritional characteristics of soymilk. Fermentation, especially with Bifidobacteria, also makes the proteins present more digestible and reduces the contents of soy oligosaccharides, stacchiose, and raffinose, which can cause digestive problems (Liu, 1997). Tofu is thought to be a good medium for the growth of lactic acid bacteria due to a high protein content and $\mathrm{pH}$ close to 
neutral. During fermentation and growth of probiotic cultures a soy product becomes a product with functional properties (Jooyandeh, 2011).

The objective of our study was to develop, under laboratory conditions, a production method for a functional product, tofu with the addition of probiotic bacteria belonging to the genera Lactobacillus and Bifidobacterium, that would have an appropriately high amount of probiotic bacteria and desired sensory qualities.

\section{MATERIAL AND METHODS}

\section{Experiment design}

Tests were divided into three stages. The aim of the first stage was to select the most appropriate strain / strain mixture for tofu production. All tofu samples were prepared in the same way, namely curd was formed as a result of the addition of
$\mathrm{CaSO}_{4}$, then selected probiotic bacteria strains (A, B, C and D) were added and incubation was performed at the temp. of $37^{\circ} \mathrm{C}$ for $20 \mathrm{~h}$. Selection was performed taking into account sensory characteristics and microbiological quality of tofu samples. The second stage included selecting conditions for tofu production. One strain of probiotic bacteria was used during four methods of tofu production $(1,2$, 3 and 4), and selection criteria included sensory characteristics of samples and their microbiological quality. The third stage of tests included a storage test for selected tofu samples at the temp. of $4^{\circ} \mathrm{C}$ for 15 days. Curds were formed as a result of adding $\mathrm{CaSO}_{4}$, then Lactobacillus casei ŁOCK 0900 bacteria were added and samples were incubated at the temp. of $37^{\circ} \mathrm{C}$ for $20 \mathrm{~h}$. Control tofu was prepared without probiotic bacteria, and there was no stage of incubation at elevated temperatures. Figure 1 presents a test design.

Step

1. Selection of strain

Figure 1 Scheme of experiment

\section{Bacterial strains and culture conditions}

Test materials included strains of probiotic bacteria: Bifidobacterium animalis ssp. lactis BB-12 (Chr. Hansen) and Lactobacillus casei ŁOCK 0900 (Motyl $\boldsymbol{e}$ al., 2009) and Lactobacillus paracasei ŁOCK 0919. The Lactobacillus strains were derived from the Collection of Pure Cultures of Industrial Microorganisms, Institute of Fermentation Technology and Microbiology at the Technical University of Łodź.

Stock cultures were prepared by growing the microorganism two successive times in MRS broth (Biokar Diagnostic), each time for $24 \mathrm{~h}$ at $37^{\circ} \mathrm{C}$. Cultures prepared with this method were centrifuged, washed twice with saline, and biomass was suspended in $10 \mathrm{ml}$ of soy beverage. Then $1 \mathrm{ml}$ of the suspension was added per $100 \mathrm{~g}$ of tofu. Four inocula were prepared and used for tofu production:

A. culture mixture (1:1 rate) of $L$ b. paracasei ŁOCK 0919 (10.19 log CFU/g) and Bifidobacterium animalis ssp. lactis BB-12 (9.16 log CFU/g),

B. culture mixture (1:1 rate) Lb. casei ŁOCK 0900 (9.26 log CFU/g) and Bifidobacterium animalis ssp. lactis BB-12 (9.16 log CFU/g),

C. monoculture of $L b$. casei ŁOCK $0900(9.26 \log \mathrm{CFU} / \mathrm{g})$,

D. monoculture of Lb. paracasei LOCK 0919 (10.19 $\log$ CFU/g).

\section{Preparation of probiotic-fermented tofu}

Tofu was prepared under laboratory conditions. Raw materials included soy milk coming from soy beans (Sante, Poland). Nutritional values of soy beans, according to manufacturer (Sante, Poland) declaration, per $100 \mathrm{~g}$ was: $34.3 \mathrm{~g}$ protein, $17.0 \mathrm{~g}$ sugars, $19.6 \mathrm{~g}$ fat, $240 \mathrm{mg}$ calcium. Soy milk was produced from soy beans according to $\mathbf{~ g ~}$ et $\mathbf{a l}$. (2008). Soy beans were washed and soaked for 12 hours in cold distilled water. Soaked beans were mashed and distilled water at the 1:6 (w:v) ratio was added. Mixed beans were filtrated through a sterile gauze, and as a result soy milk was obtained. This product, as well as natural soy beverage and instant soy beverage were pasteurised for 10 minutes, and then brought to the temperature of $80-85^{\circ} \mathrm{C}$ and $0.5 \%$ calcium sulphate $\left(\mathrm{CaSO}_{4}\right)$ (Sigma Aldrich) was added. The whole mixture was mildly mixed and left for 10 minutes so as protein could coagulate. Curds were pressed, formed and optionally probiotic bacteria at the average amount of $9.3 \log \mathrm{CFU} / \mathrm{cm}^{3}$ per $100 \mathrm{~g}$ of tofu were added. The following four methods of tofu production were applied:

1. the addition of selected cultures of probiotic bacteria to the soy beverage (without $\mathrm{CaSO}_{4}$ ) and incubation at the temp. of $37^{\circ} \mathrm{C}$ for $22 \mathrm{~h}$

2. the formation of curds with $\mathrm{CaSO}_{4}$, and then the addition of selected cultures of probiotic bacteria and incubation at the temp. of $37^{\circ} \mathrm{C}$ for $2 \mathrm{~h}$, according by Ng et al. (2008);

3. the formation of curds with $\mathrm{CaSO}_{4}$, and then the addition of selected cultures of probiotic bacteria and incubation at the temp. of $37^{\circ} \mathrm{C}$ for $20 \mathrm{~h}$

4. the formation of curds with $\mathrm{CaSO}_{4}$, and then storage at the temp. of $4{ }^{\circ} \mathrm{C}$ for $24 \mathrm{~h}$ (a control sample).

In order to compare the quality of products obtained commercial tofu by Solida Food (Poland) was used.

\section{Sensorial analyses}

In the tests the following methods of sensory analysis were used: an order (ranking) method and a scoring method. According to the order method a judge had to rank several randomly received samples from the best to the worst in terms of palatability. The best sample received the rank 1 , and subsequent samples ranks of 2, 3, 4, etc. Whereas the scoring method used an unstructured graphic scale [0-10 conventional units - c.u.] - judges had to evaluate desirability of the smell, taste, texture and general quality on this scale. Persons participating in a sensory analysis were trained with regard to basic sensory evaluation methods. The conditions and assessment mode were determined in accordance with Meilgaard et al. (1999).

\section{Microbial analyses}

Microbiological tests were performed in accordance with (ISO:15214:1998). The number of mesophilic cells of lactic acid bacteria (LAB) was determined with a plate method using deep inoculation on the MRS medium (Biokar Diagnostic). Plates were incubated at the temp. of $30^{\circ} \mathrm{C}$ for 72 hours. The number of Lactobacillus cells was determined using a selective medium - Rogosa-Agar (Merck). Plates were incubated at the temp. of $37^{\circ} \mathrm{C}$ for 72 hours in accordance with the manufacturer's instructions. Selective BSM Agar by Sigma Aldrich was used to determine the Bifidobacterium cells. Plates were incubated in anaerobic jar at the temp. of $37^{\circ} \mathrm{C}$ for 72 hours. The total number of bacteria (TVC) was determined using nutrient agar (Biokar Diagnostic). Plates were incubated at the temp. of $37^{\circ} \mathrm{C}$ for 48 hours.

Each time a mass of $10 \mathrm{~g}$ of tofu was taken aseptically from a jar, homogenized with $90 \mathrm{~mL}$ of sterile peptone water (Biokar Diagnostic), and decimal dilutions in sterile peptone water were prepared. Tests were performed immediately after appropriate samples had been prepared and during storage on day $0,5,10$ and 15 .

\section{Determination of $\mathbf{p H}$}

Value of $\mathrm{pH}$ was measured in homogenates with the ELMETRON CP551 device. The result was read with the accuracy of 0.05 .

\section{Statistical analysis}

Each experiment was performed in three independent repetitions. The statistical analysis of results was performed with the STATISTICA 10.0 software. A variance analysis, Friedman test and T-Student test were performed, and the simple correlation coefficient was calculated. In the case of data regarding sensory evaluations the significance level of 0.01 was used, and of 0.05 in the case of other data. 


\section{RESULTS AND DISCUSSION}

\section{Selection of strain - Step 1}

Tofu fermented by monocultures of Lactobacillus casei ŁOCK 0900 (C) and Lactobacillus paracasei ŁOCK 0919 (D) was evaluated slightly better with regard to taste and smell criteria, in comparison with tofu with the addition of mixed cultures of Lactobacillus casei ŁOCK 0900 and Bifidobacterium animalis ssp. lactis BB-12 (B) and Lactobacillus paracasei ŁOCK 0919 and Bifidobacterium animalis ssp. lactis BB-12 (A). However, it was concluded that there are no statistically significant differences with regard to the sensory quality between four tested tofu samples ( $\mathrm{p}=0.72$ and $\mathrm{p}>0.01$ ) what can be seen in figure

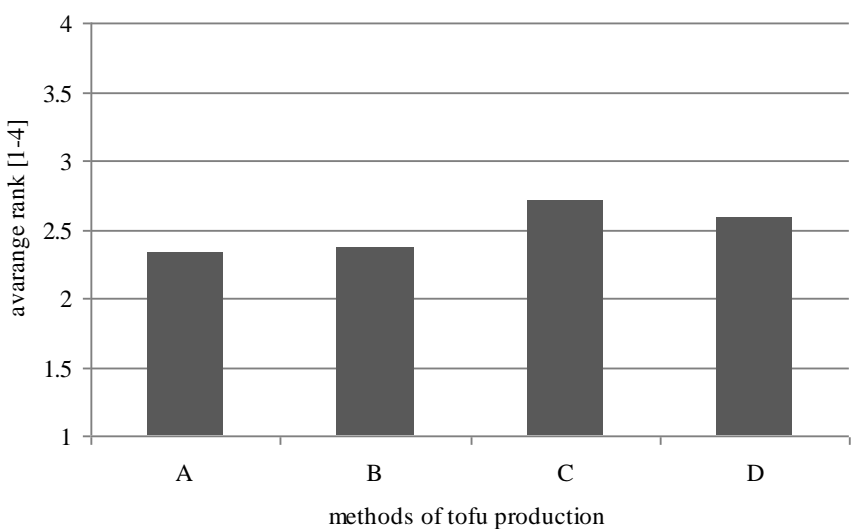

Figure 2 Avarage ranks values of tofu desirability fermented with different strains of probiotic bacteria (ranking method; 4- most desirable; 1- less desirable; $\mathrm{n}=25$ )

Explanatory notes:

A - tofu made with addition culture mixture (1:1 rate) $L b$. paracasei ŁOCK 0919 and Bifidobacterium animalis ssp lactis BB-12 ; B - tofu made with addition culture mixture $(1: 1$ rate) Lb. casei ŁOCK 0900 and Bifidobacterium animalis ssp lactis BB-12; C - tofu made with monoculture addition of $L b$. casei ŁOCK 0900 ; D - tofu made with monoculture addition of $L b$. paracasei ŁOCK 0919

Simultaneously, a sensory analysis with the scoring method was performed (results are not presented). Quality factors that were evaluated included: smell, taste, texture and general quality. Also in the course of this analysis there were no statistically significant differences between individual quality factors of tofu fermented with different cultures of probiotic strains $(p>0.01)$.

It was concluded that desirability of individual types of tofu was evaluated between 4 and 6 c.u. on average, depending on a studied quality factor what indicated moderate approval of this product. Tofu fermented with monocultures of Lactobacillus (C and D) received slightly higher scores for taste and texture.

Many studies indicate that the addition of lactic acid bacteria cultures to soy products increases the acceptability and desirability of these products. "Grasslike", "flour-like" taste of soy that is not accepted by many consumers is masked by "acid" taste which is typical of lactic acid fermentation (Dalev et al., 2006; Kandiah and Laird, 2002; Miguel et al., 2004; Wenrich and Cason, 2004). Some authors also state that when judges have been informed of healthy properties of soy prior to a sensory analysis soy products are more accepted by them (Teh et al., 2007).

Experiments studying the survival of probiotics indicate that soymilk is a good substrate for bacteria such as the Lactobacillus and Bifidobacteria species (Rivera-Espinoza and Gallardo-Navarro, 2010).

The strains of Lactobacillus casei LOCK 0900 and Lactobacillus paracase LOCK 0919 used in this study were selected on the basis of results of in vitro studies, which comprised determination of resistance to the acidity of gastric juice and to bile, adherence to epithelial cells, and antimicrobial activity. These strains showed strong antagonistic activity against gram-positive and gramnegative pathogens (Cukrowska et al., 2009). It has been demonstrated that a mixture of three strains from the Lactobacillus genus ( $L b$. casei ŁOCK 0900, Lb. casei ŁOCK 0908, Lb. paracasei ŁOCK 0919) has probiotic properties consisting in modulating immune responses in children with atopic dermatitis as a result of induction of Th1 cytokine production and simultaneous inhibition of the production of proallergic interleukin-5 (Cukrowska et al., 2010). On the other hand, Bifidobacterium animalis ssp. lactis BB-12 has beneficial effects on the human health, as it stimulates the body immune system, relieves constipation, and reduces the risk of and the duration of diarrhoeas. Furthermore, it was observed that BB-12, ŁOCK 0900 and ŁOCK 0919 strains have beneficial effects in terms of treatment of atopic dermatitis in children (Chr. Hansen, 2013; Cukrowska et al., 2010). It seems that applied bacterial inocula should play their role in a milk-free product such as tofu, especially indicated for those with milk protein allergy, lactose intolerance or vegetarians.

In tofu fermented with mixed cultures (A and B) the number of lactic acid bacteria (LAB) was 3-4 log orders CFU/g higher in comparison with tofu with the addition of monocultures (C and D). The number of Bifidobacterium in the tested product did not exceed $10^{3} \mathrm{CFU} / \mathrm{g}$ and that tofu is a good carrier of Lactobacillus casei ŁOCK 0900 and Lactobacillus paracasei ŁOCK 0919 strains, as the number of bacteria belonging to the Lactobacillus genus was $>10^{8}$ $\mathrm{CFU} / \mathrm{g}$ in tofu (Tab 1).

Table 1 Count of lactic acid bacteria (LAB), total viable count (TVC), number of Lactobacillus, number of Bifidobacterium and $\mathrm{pH}$ value in tofu with addition of probiotic cultures after 20 hours of fermentation process at $37^{\circ} \mathrm{C}$

\begin{tabular}{|c|c|c|c|c|c|c|}
\hline & Type of tofu & $\begin{array}{c}\text { Count of } \\
\text { Lactobacillus } \\
{[\log \text { CFU/g] }}\end{array}$ & $\begin{array}{c}\text { Count of } \\
\text { Bifidobacterium } \\
{[\log \text { CFU/g] }}\end{array}$ & $\begin{array}{c}\text { Count of lactic acid } \\
\text { bacteria LAB } \\
{[\log \text { CFU/g] }}\end{array}$ & $\begin{array}{c}\text { Total viable count } \\
\text { TVC } \\
{[\log \mathrm{CFU} / \mathrm{g}]}\end{array}$ & $\mathrm{pH}$ value \\
\hline A & $\begin{array}{l}\text { Tofu with addition } \\
\text { Lb.paracasei }+ \\
\text { Bifidobacterium } \\
\end{array}$ & $8.77 \pm 0.12$ & $<3$ & $9.52 \pm 0.02$ & $7.78 \pm 0.42$ & $4.77 \pm 0.04$ \\
\hline B & $\begin{array}{l}\text { Tofu with addition } \\
\text { Lb.casei }+ \\
\text { Bifidobacterium }\end{array}$ & $8.99 \pm 0.06$ & $<3$ & $9.77 \pm 0.02$ & $7.28 \pm 0.40$ & $4.79 \pm 0.08$ \\
\hline $\mathrm{C}$ & $\begin{array}{l}\text { Tofu with addition } \\
\text { Lb.casei }\end{array}$ & $8.94 \pm 0.08$ & - & $9.56 \pm 0.06$ & $7.66 \pm 0.21$ & $5.05 \pm 0.11$ \\
\hline D & $\begin{array}{l}\text { Tofu with addition } \\
\text { Lb.paracasei }\end{array}$ & $9.10 \pm 0.08$ & - & $9.28 \pm 0.06$ & $8.53 \pm 0.31$ & $5.11 \pm 0.09$ \\
\hline
\end{tabular}

Increased sensitivity to oxygen and an increased amount of metabolites such as hydrogen peroxide, ethanol and bacteriocins produced by lactic acid bacteria might have contributed to a reduced number of bifidobacteria. Similar studies were conducted by Wang $\boldsymbol{e t}$ al. (2002) and have demonstrated that the growth of bifidobacteria in fermented soy beverage contributes to the increased amount of lactic acid bacteria, and this correlation depends on individual species characteristics. In our own studies we observed a strong negative correlation between the general quality and the number of lactic acid bacteria in samples ( $\mathrm{r}=$ $-0.95)$. An increased number of LAB also resulted in reduced $\mathrm{pH}$ in samples ( $\mathrm{r}=$ -0.74 ). On the other hand, it was observed that the number of Lactobacillus bacteria in study samples was the factor determining the palatability of tofu ( $\mathrm{r}=$ 0.75). High levels of LAB in the product were correlated with significantly reduced $\mathrm{pH}$. However, product acidity above $4.6 \mathrm{pH}$ did not inhibit the growth of saprophytic microflora what is confirmed by generally high of total viable count (TVC) (Tab 1). Similarly in the studies by Liu et al. (2006), as in our own studies, it was showed that during $6 \mathrm{~h}$-fermentation of soy cheese with varied strains of $\mathrm{Lb}$. rhamnosus at the temperature of $37^{\circ} \mathrm{C} \mathrm{pH}$ was reduced from 5.9 to 4.7-5.2 correlated with a increase in the number of lactic acid bacteria cells.

Taking into account the results of experiments performed the strain $L b$. case ŁOCK 0900 was selected for further tests. A tofu sample (C) contained high levels of LAB after fermentation and in addition, low level of TVC. A tofu sample (C) had the highest score for palatability and the best taste and texture.

\section{Selection of manufacturing conditions - Step 2}

It was concluded that there are statistically significant differences between studied tofu samples with regard to a criterion of the sensory quality (fig. 3). 
SMELL

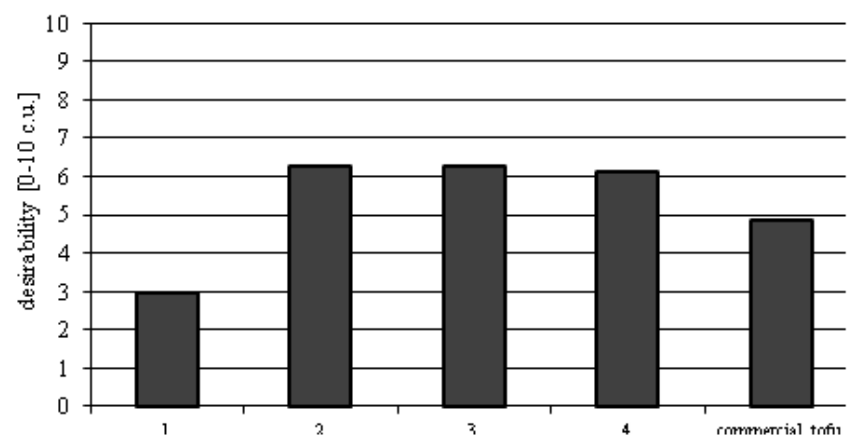

TEXTURE

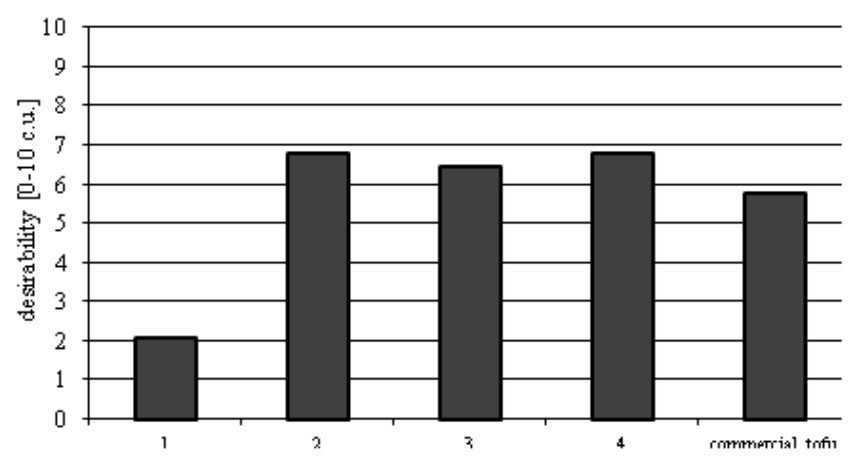

TASTE

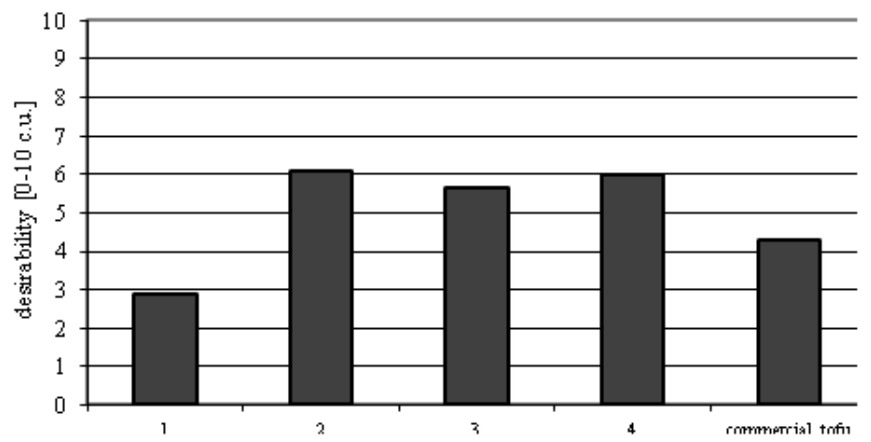

OVERALLQUALITY

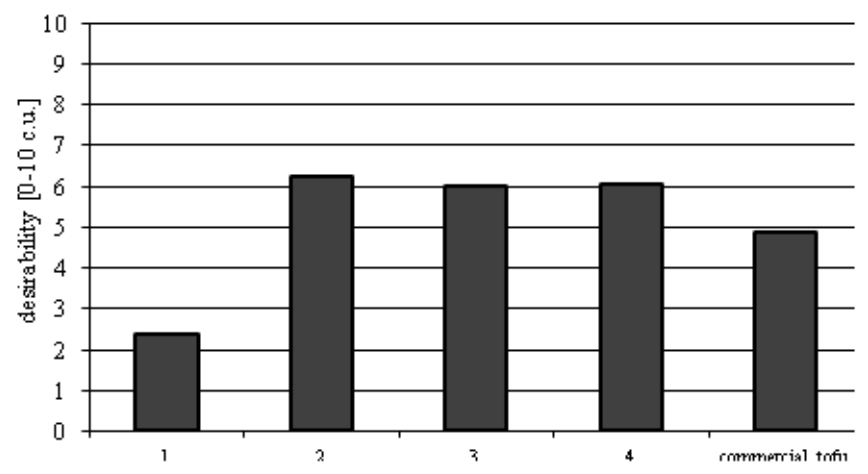

Figure 3 Average values of desirability smell, taste, texture and overall quality of tofu made by different ways, compared to commercial tofu (scoring method, $10-$ most desirable, 1 - less desirable, $\mathrm{n}=33$ )

Explanatory notes:

1-tofu made by addition Lactobacillus casei LOCK 0900 to the soy beverage (without $\mathrm{CaSO}_{4}$ ) and incubation at the temp. of $37^{\circ} \mathrm{C}$ for $22 \mathrm{~h}, 2-\mathrm{CaSO}_{4}$, and then the addition of Lactobacillus casei $\mathrm{ŁOCK} 0900$ and incubation at the temp. of $37^{\circ} \mathrm{C}$ for $2 \mathrm{~h}, 3$ - tofu made by addition $\mathrm{CaSO}_{4}$, and then the addition of Lactobacillus casei ŁOCK 0900 and incubation at the temp. of $37^{\circ} \mathrm{C}$ for $20 \mathrm{~h}, 4$-tofu made by addition $\mathrm{CaSO}_{4}$, and then storage at the temp. of $4^{\circ} \mathrm{C}$ for $24 \mathrm{~h}$ (a control sample).
Average values of evaluations of tested samples were statistically significantly different $(\mathrm{p}<0.01)$, in the test conducted with the ranking method and in the other conducted with the scaling method. It was concluded that tofu (1) manufactured with probiotic bacteria cultures, without calcium sulphate, was significantly worse than other samples. Judges emphasised acid, pungent taste of tofu, and too loose texture that resembled yoghurt curds. Tofu with the addition of probiotic bacteria cultures produced with other methods was evaluated much better, comparably to control tofu (4) and commercial tofu.

The highest scores in terms of desirability of taste, smell, texture and general quality in the scaling method, and of palatability in the ranking method were given to tofu (2) produced with the addition of $\mathrm{CaSO}_{4}$, followed by the addition of probiotic bacteria cultures incubated at temp. of $37^{\circ} \mathrm{C}$ for $2 \mathrm{~h}$. However, 20 hours fermented tofu (3) was also high evaluated regarding smell, texture, taste, overall quality, compared to (2) tofu ( $p>0.01)$. The judges pointed to fresh, sour taste and pleasant smell of 20 hours fermented tofu.

It was concluded that both commercial and control tofu (4) had similar microbiological quality (fig. $4 \mathrm{~A}$ and $\mathrm{B}$ ). The total number of microorganisms and the number of lactic acid bacteria cells in both products were similar and did not exceed the value of $6 \log \mathrm{CFU} / \mathrm{g}$ - for LAB and $4 \log \mathrm{CFU} / \mathrm{g}$ - for TVC. Furthermore, the acidity of control and commercial products was similar and the $\mathrm{pH}$ value was above 6

It was observed that the number of lactic acid bacteria was the highest in tofu incubated at the temp. of $37^{\circ} \mathrm{C}$ for $20 \mathrm{~h}(9.36 \mathrm{log} \mathrm{CFU} / \mathrm{g})$ and $22 \mathrm{~h}(10.22 \mathrm{log}$ $\mathrm{CFU} / \mathrm{g}$ ). Also $\mathrm{pH}$ of these products was significantly lower (sample $1-\mathrm{pH}=4.33$, sample $3-\mathrm{pH}=5.05$ ) in comparison with tofu incubated for $2 \mathrm{~h}$ at the temp. of $37^{\circ} \mathrm{C}$ (sample $2-\mathrm{pH}=6.02$ ). The 2 hours fermentation time was established according to $\mathbf{N g}$ et al. (2008). The authors proposed the 2 hours at $37^{\circ} \mathrm{C}$ incubation time to tofu production and suggested that it was an adaptation period, which ensured higher viability of probiotics during storage. The longer the fermentation time, the higher number of lactic acid bacteria cells and the lower $\mathrm{pH}$ were observed in tested samples.
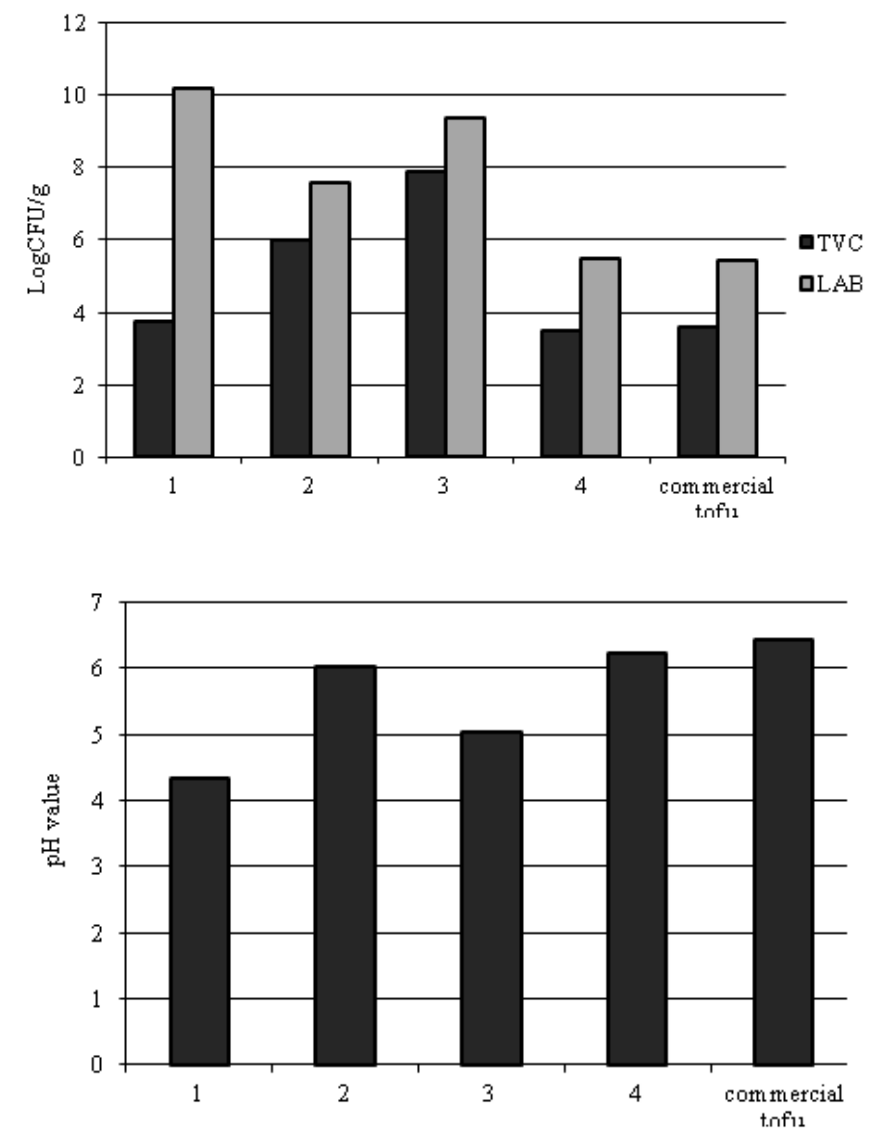

B

Figure 4 Total viable count (TVC) and lactic acid bacteria count (LAB) (a) and changes of $\mathrm{pH}$ value (b) in tofu made by different ways, compared to commercial tofu.

Explanatory notes:

1-tofu made by addition Lactobacillus casei ŁOCK 0900 to the soy beverage (without $\mathrm{CaSO}_{4}$ ) and incubation at the temp. of $37^{\circ} \mathrm{C}$ for $22 \mathrm{~h}, 2-\mathrm{CaSO}_{4}$, and then the addition of Lactobacillus casei ŁOCK 0900 and incubation at the temp. of $37^{\circ} \mathrm{C}$ for $2 \mathrm{~h}, 3$ - tofu made by addition $\mathrm{CaSO}_{4}$, and then the addition of Lactobacillus casei ŁOCK 0900 and incubation at the temp. of $37^{\circ} \mathrm{C}$ for $20 \mathrm{~h}, 4$-tofu made by addition $\mathrm{CaSO}_{4}$, and then storage at the temp. of $4^{\circ} \mathrm{C}$ for $24 \mathrm{~h}$ (a control sample). 
$\mathrm{Ng}$ et al. (2008) observed inhibition of the total number of aerobic microorganisms in tofu with probiotic bacteria ( $L b$. bulgaricus and $L b$. fermentum) addition. In our own studies slightly different results were obtained; in the control sample there was $<4 \log \mathrm{CFU} / \mathrm{g}$ cells of the total number of aerobic bacteria. Moreover, it was observed that the total number of microorganisms in tofu samples was higher when the incubation at the temp. of $37^{\circ} \mathrm{C}$ was longer (in tofu incubated for $2 \mathrm{~h}-5.98 \mathrm{log} \mathrm{CFU} / \mathrm{g}$; in tofu incubated for $20 \mathrm{~h}-7.9 \mathrm{log}$ $\mathrm{CFU} / \mathrm{g}$ ). However, in tofu incubated for $22 \mathrm{~h}$ there were only $3.74 \mathrm{log} \mathrm{CFU} / \mathrm{g}$ of the total number of microorganisms. It was probably associated with lowering $\mathrm{pH}$ of this tofu sample (1) to 4.33 what resulted in the inhibition of growth of the majority of saprophytic bacteria.

Tofu fermented for 20 hours at the temperature of $37^{\circ} \mathrm{C}$ was selected for further tests. This product had desired low $\mathrm{pH}$ and appropriately high $\left(>10^{9} \mathrm{CFU} / \mathrm{g}\right)$ number of lactic acid bacteria - Lactobacillus casei ŁOCK 0900. It received high scores in terms of desirability of smell, taste and texture. This tofu sample was perceived as the best in terms of general quality.

\section{Storage trial - Step 3}

Many authors emphasise that tofu and other soy products are a good medium for probiotics (Liong et al., 2009; Ng et al., 2008; Donkor et al., 2007; Zielińska et al., 2008). In our studies during 15 days of storage tofu with probiotic bacteria at $4^{\circ} \mathrm{C}$ the number of $\mathrm{LAB}$ was at the high level, above $10^{9} \mathrm{CFU} / \mathrm{g}$, whereas Liong et al. (2009) have found that the number of Lb. acidophilus FTCC 0291 in tofu during 20 days of cold storage was at the level above $10^{6} \mathrm{CFU} / \mathrm{g}$.

In the present study on day 15 th of storage the microbiological quality of both samples statistically significantly changed. In tofu with probiotics the total viable count of bacteria (TVC) decreased by $1 \mathrm{log}$ order, whereas in control tofu TVC increased by approx. $4 \log$ orders, and the number of LAB by $2 \log$ orders. The increase in the TVC in control tofu $(\mathrm{r}=0.80)$ and in tofu with the addition of $L b$. casei ŁOCK $0900(\mathrm{r}=0.83)$ was present together with the increase in the LAB Moreover, a strong positive correlation was observed between the TVC and $\mathrm{pH}$ in control tofu $(\mathrm{r}=0.81)$. On the other hand, the increase in the number of $L b$ casei ŁOCK 0900 bacteria caused a decrease in $\mathrm{pH}$ in a sample with probiotics $(\mathrm{r}=-0.85)$. The results of storage tests are presented in table 2

Table 2 Changes of lactic acid bacteria count, total viable count and $\mathrm{pH}$ value in tofu during 15 days of storage at temp. $4^{\circ} \mathrm{C}$

\begin{tabular}{lcccc}
\hline \hline \multirow{2}{*}{ Samples } & Day & $\begin{array}{c}\text { Count of } \\
\text { lactic acid } \\
\text { bacteria LAB } \\
{[\text { CFU/g] }}\end{array}$ & $\begin{array}{c}\text { Total viable } \\
\text { count } \\
\text { TVC [CFU/g] }\end{array}$ & pH value \\
\hline \hline & 0 & $6.82 \pm 0.02$ & $3.52 \pm 0.20$ & $6.39 \pm 0.10$ \\
\cline { 2 - 5 } & 5 & $5.79 \pm 0.01$ & $3.84 \pm 0.40$ & $6.45 \pm 0.20$ \\
\cline { 2 - 5 } Control tofu & 10 & $5.61 \pm 0.04$ & $4.15 \pm 0.03$ & $6.86 \pm 0.10$ \\
\cline { 2 - 5 } & 15 & $7.76 \pm 0.10$ & $8.47 \pm 0.20$ & $7.13 \pm 0.20$ \\
\hline $\begin{array}{l}\text { Tofu with } \\
\text { addition }\end{array}$ & 0 & $9.62 \pm 0.10$ & $7.61 \pm 0.20$ & $5.33 \pm 0.05$ \\
\cline { 2 - 6 } $\begin{array}{l}\text { Lactobacillus } \\
\text { after 20h of } \\
\text { fermentation } \\
\text { at 37 }\end{array}$ & 5 & $9.63 \pm 0.06$ & $7.62 \pm 0.06$ & $5.41 \pm 0.10$ \\
\cline { 2 - 5 } & 10 & $9.45 \pm 0.04$ & $7.33 \pm 0.20$ & $5.61 \pm 0.10$ \\
\hline \hline
\end{tabular}

Also Ng et al. (2008) observed that the number of Lb. bulgaricus FTCC 0411 and Lb. fermentum FTD 13 bacteria in tofu during 9 days of cold storage was at the level of $10^{7}-10^{8} \mathrm{CFU} / \mathrm{g}$, and the TVC decreased by 1 log order, and $\mathrm{pH}$ slightly changed, what confirms the results of our tests. On the other hand Liu et al. (2006) have observed slow reduction of $\mathrm{pH}$ and the number of probiotic bacteria cells in the soy cheese with addition of probiotic Lb. rhamnosus bacteria stored for 30 days at $10^{\circ} \mathrm{C}$ The most significant changes were observed between day 5 and 15 of storage, just like in our case.

When added to foods lactic acid bacteria increase microbiological safety of foods. It is associated with the fact that these bacteria produce organic acids as well as other substances with bacteriostatic properties (El-Shouny et al. 2013). It was observed that during storage of tofu with the addition of $L b$. casei ŁOCK 0900 the total number of microorganisms indicating the presence of coexisting microflora reduced contrary to a control sample where on day 15 there was intensive growth of microorganisms. Tofu with probiotics preserved appropriate microbiological quality for a longer period of time. It was concluded that the addition of Lactobacillus bacteria had a positive effect on tofu stability.

\section{CONCLUSION}

Soy is a valuable raw material for the production of high-protein, low-energy and functional foods. In view of its benefits it is more and more often used to produce processed foods not only in Asia but also in Europe. Many research studies have proven that soy is a good medium for the growth of probiotic bacteria. The fermentation process that is used increases the nutritional value of soy products, and moreover, helps eliminate soy taste ("beanie taste") that is unacceptable for many consumers. In a present studies we have developed a method to produce a new functional product based on soy.

It was concluded that tofu produced under laboratory conditions is a good medium for the growth of lactic acid bacteria the number of which maintained at the high level $\left(10^{9}-10^{10} \mathrm{CFU} / \mathrm{g}\right)$, and especially it regards probiotic bacteria from the Lactobacillus genus $\left(10^{8}-10^{9} \mathrm{CFU} / \mathrm{g}\right)$. It was also concluded that the addition of probiotic bacteria to tofu increased palatability and general quality of studied tofu samples. We have found, that it is possible to produce tofu with probiotic bacteria that has acceptable sensory characteristics, comparable to a commercial product, and a high number of probiotic bacteria and appropriate stability, therefore the product could be considered as a functional one. Tofu with the addition of probiotic bacteria can be an alternative for vegetarians, and taking into account specific properties of bacteria that are used it may affect body immunomodulation and inhibit allergic reactions.

\section{REFERENCES}

CHR-HANSEN 2013. Bifidobacterium BB-12. Internet www.chrhansen.com/index.php?id=2260, 20.10.2013.

CUKROWSKA B., MOTYL I., KOZÁKOVÁ H., SCHWARZER M., GÓRECKI R.K., KLEWICKA E., ŚLIŻEWSKA K., LIBUDZISZ Z. 2009. Lactobacillus Strains : in vitro and in vivo Studies. Folia Microbiologica, 54, 6 , 533-537. DOI 10.1007/s12223-009-0077-7

CUKROWSKA B., ROSIAK I., KLEWICKA E., MOTYL I., SCHWARZER M., LIBUDZISZ Z., KOZÁKOVÁ H. 2010. Impact of Heat-Inactivated Lactobacillus casei and Lactobacillus paracasei Strains on Cytokine Responses in Whole Blood Cell Cultures of Children with Atopic Dermatitis. Folia Microbiologica, 55, 3, 277-280. DOI 10.1007/s12223-010-0041-6

DALEV D., BIELECKA M., TROSZYŃSKA A., ZIAJKA S., LAMPARSKI G. 2006. Sensory quality of new probiotic beverages based on cheese whey and soy preparation. Polish Journal of Food and Nutrition Sciences, 15/56, 71-77.

DONKOR O.N., NILMINI S.L.I., STOLIC P., VASILJEVIC T., SHAH N.P 2007. Survival and activity of selected probiotic organisms in set-type yogurt during cold storage. Int Dairy J, 17, 657-665. DOI:10.1016/j.idairyj.2006.08.006 EL-SHOUNY W., ABO-KAMAR A., RAGY S. 2013. Characterization of the partially purified plantarcin SR18 produced by Lactobacillus plantarum SR18. Journal of Microbiology, Biotechnology and Food Sciences, 2 (5) 2301-2305. FAO/WHO 2002. (Food and Agricuture Organization/World Health Organization). Guidelines for the Evaluation of Probiotics in Food. Report a Joint FAO/WHO Working Group. London, Ontario, Canada. FAO/WHO, April 30 and May 1, 1-11.

ISO 15214:1998, Microbiology of food and animal feeding stuffs -- Horizontal method for the enumeration of mesophilic lactic acid bacteria Colony-count technique at 30 degrees $\mathrm{C}$.

JOOYANDEH H. 2011. Soy Products as Healthy and Functional Foods. MiddleEast Journal of Scientific Research, 7, 1, 71-80.

KANDIAH J., LAIRD J.B.S. 2002. Sensory attributes and acceptance of flavored soy nuts by college students. Nutrition Research 22, 405-410. DOI:10.1016/S0271-5317(02)00360-3

LIONG M.-T., EASA A. M., LIM P.-T., KANG J.-Y. 2009. Survival, growth characteristics and bioactive potential of Lactobacillus acidophilus in a soy-based cream cheese. Journal of the Science of Food and Agriculture, 89, 8, 1382-1391. DOI: $10.1002 /$ jsfa.3598

LIONG, M.T. 2007. Probiotics: a critical review of their potential role as antihypertensives, immune modulators, hypocholesterolemics, and perimenopausal treatments. Nutrition reviews, 65(7), 316-328. DOI: http://dx.doi.org/10.1111/j.1753-4887.2007.tb00309.x 316-328

LIU D.M. Li L., YANG X.-Q., LIANG S.-Z., WANG J.-S. 2006. Survivability of L. rhamnosus in Soy Cheese, Food Technol. Biotechnol. 44 (3) 417-422.

LIU K. 1997. Soybeans: chemistry technology and utilization. New York: Chapman and Hall. pp. 415-8.

MEILGAARD M., CIVILlE G.V., CARR B.T. (1999): Sensory evaluation techniques, $3^{\text {rd }}$ edn. CRC Press, Boca Raton.

MIGUEL D.P., VALDEZ G., ROSSI E.A. 2004. Sensory and chemical aspects of frozen soy yogurt fermented with Enterococcus faecium and Lactobacillus jugurti. Alimentos e Nutricao Araraquara, 15, 3, 197-201.

MOTYL I., KLEWICKA E., LIBUDZISZ Z., 2009. Lactobacillus casei. Polish Patent Application No. 382760.

NAGPAL R., KUMAR A., KUMAR M., BEHARE P. V., JAIN S., YADAV H 2012. Probiotics, their health benefits and applications for developing healthier foods: a review; FEMS Microbiology Letters, 334, 1- 15 DOI: http://dx.doi.org/10.1111/j.1574-6968.2012.02593.x 1-15

NG K.-H., LYE H.-S., EASA A.-M., LIONG M.-T. 2008. Growth characteristics and bioactivity of probiotics in tofu-based medium during storage. Annals of Microbiology, 58, 3, 77-487. DOI: 10.1007/BF03175546 
OBATOLU V.A. 2008. Effect of different coagulants on yield and quality of tofu from soymilk, Eur Food Res Technol, 226, 467-472. DOI: 10.1007/s00217-0060558-8

OELSCHLAEGER T.A. 2010. Mechanisms of probiotic actions - a review. Int J. Med. Microbiol., 300, 57-62. 83. DOI:10.1016/j.ijmm.2009.08.005

OOI L.-G., LIONG M.-T. 2010. Cholesterol-Lowering Effects of Probiotics and Prebiotics: A Review of in Vivo and in Vitro Findings. Int. J. Mol. Sci., 11, 24992522. DOI:10.3390/ijms11062499

RIVERA-ESPINOZA Y., GALLARDO-NAVARRO Y. 2010. Non-dairy probiotic products. Food Microbiology, 27, 1-11. DOI:10.1016/j.fm.2008.06.008

SCALABRINI P., ROSSI M., SPETTOLI P., MATTEUZZI D. 1998 Characterization of Bifidobacterium strains for use in soymilk fermentation. International Journal of Food Microbiology, 39, 213-21. DOI:10.1016/S01681605(98)00005-1

TEH T., DOUGHERTY M.P., CAMIRE M.E. 2007. How Do Consumer Attitudes Influence Acceptance of a Novel Wild Blueberry-Soy Product? Journal of Food Science, 72, 7, S516-S521. DOI: 10.1111/j.17503841.2007.00463.x

TRZĄSKOWSKA M. 2013. Probiotyki w produktach pochodzenia roślinnego. Żywność Nauka Technologia Jakość, 4 (89) 5-20.

van NIEL C.W., FEUDTNER C., GARRISON M.M., CHRISTAKIS D.A. 2002 A Lactobacillus therapy for acute infectious diarrhea in children: Meta-analysis. Pediatrics, 109, 678-684. DOI: 10.1542/peds.109.4.678

VASILJEVIC T., SHAH N.P. 2008. Probiotics - from Metchnikoff to bioactives Int. Dairy J., 18,714-728. DOI:10.1016/j.idairyj.2008.03.004

WANG Y.C., YU R.C., CHOU C.C. 2002. Growth and survival of bifidobacteria and lactic acid bacteria during the fermentation and storage of cultured soymilk drinks. Food Microbiology, 19, 5, 501-508. DOI:10.1006/fmic.2002.0506

WANG Y.C., YU R.C., YANG H.Y., CHOU C.C. 2003. Sugar and acid content in soymilk fermented with lactic acid bacteria alone or simultaneously with bifidobacteria. Food Microbiol. 20, 333-338. DOI:10.1016/S07400020(02)00125-9

WANG Y.C., YU R.C., YANG H.Y., CHOU C.C. 2006. Antioxidatives activities of soymilk fermented with lactic acid bacteria and bifidobacteria. Food Microbiol. 23, 128-135. DOI:10.1016/j.fm.2005.01.020

WENRICH T.R. and CASON K.L. 2004. Consumption and perception of soy among low-income adults. J. Nutr. Edu. Behavior, 36, 3 140-145. DOI:10.1016/S1499-4046(06)60151-6

ZIELIŃSKA D., KOŁOŻYN-KRAJEWSKA D., GORYL A. 2008. Modele przeżywalności bakterii potencjalnie probiotycznych Lactobacillus casei KN291 w fermentowanym napoju sojowym. Żywność. Nauka. Technologia. Jakość, 5 (60) $126-134$ 